Research article

urn:lsid:zoobank.org:pub:0BE6D99E-905D-4094-A03F-1C40D3C07CC2

\title{
Salticidae (Arachnida: Araneae) of New Caledonia: Genus Corambis Simon, 1901
}

\author{
Barbara PATOLETA ${ }^{1, *}$ \& Marek ŻABKA ${ }^{2}$ \\ ${ }^{1,2}$ Siedlce University of Natural Sciences and Humanities, Faculty of Exact and Natural Sciences, \\ Prusa 14, 08-110 Siedlce, Poland. \\ ${ }^{*}$ Corresponding author: barbara.patoleta@uph.edu.p1 \\ 2Email: marek.zabka@uph.edu.pl \\ ${ }^{1}$ urn:1sid:zoobank.org:author:321AD5CC-4081-4319-882D-E2B3F80DB458 \\ ${ }^{2}$ urn:1sid:zoobank.org:author:65CFB20A-8CC4-43EA-9CDF-E21D2D816C68
}

\begin{abstract}
The genus Corambis Simon, 1901 includes five species; three of them, C. jacknicholsoni sp. nov., C. logunovi sp. nov. and C. pantherae sp. nov., are described here as new. The female of the C. foeldvarii Szüts, 2002 is described for the first time and a new generic diagnosis is proposed. The distribution and relationships of Corambis are discussed in terms of the geological and bioclimatic history of New Caledonia.
\end{abstract}

Keywords. Jumping spiders, New Caledonia, endemism, taxonomy.

Patoleta B. \& Żabka M. 2019. Salticidae (Arachnida: Araneae) of New Caledonia: Genus Corambis Simon, 1901. European Journal of Taxonomy 5XX: 1-18. https://doi.org/10.5852/ejt.2019.578

\section{Introduction}

New Caledonia (NC) is known for its highly diverse and endemic fauna and is one of the global biodiversity hotspots (Grandcolas et al. 2008; Heads 2010; Wulff et al. 2013). This also applies to spiders. According to WSC (2019), about 300 species are recorded from the archipelago. Given the area of $\mathrm{NC}\left(18576 \mathrm{~km}^{2}\right)$, the number is quite substantial, although it certainly is underestimated, as only a few comprehensive investigations have been carried out there in modern times (Platnick \& Forster 1989, 1993; Platnick 1993; Raven 1994).

Jumping spiders in NC are formally represented by 31 species (WSC 2019), but Patoleta (2002, 2017, pers. obs.) has recorded at least 51 species, some of them new, including those described here.

The genus Corambis was established by Simon (1901) for the female of C. insignipes (Simon, 1880), later studied by Żabka (1988). In 2002 Szüts described the missing male, added one new species, C. foeldvarii, and proposed a generic diagnosis. Both Simon and Szüts suggested relationships with other hairy, elongate and flat-bodied genera such as Mendoza Peckham \& Peckham, 1894, Marpissa C.L. Koch, 1846, Holoplatys Simon, 1885, Ocrisiona Simon, 1901 and Paraplatoides Żabka, 1992. Recent molecular data (Maddison et al. 2008; Maddison 2015) did not support these views and revealed 
close affinities with Rhondes Simon, 1901, Lystrocteisa Simon, 1884, Penionomus Simon, 1903 and Rogmocrypta Simon, 1900 - all of them belonging to a New Caledonian lineage within the Astoida clade.

\section{Material and methods}

This paper is based on specimens deposited in the collections listed below. The drawings were made using a grid system. The dissected epigynes were digested in $10 \% \mathrm{KOH}$, stained in Chlorazol Black E and studied under a transmission microscope. Dimensions (in $\mathrm{mm}$ ) were measured with MultiScan software. Photographs were taken with a Nikon D5200 camera and a Nikon SMZ1000 stereo microscope, and digitally processed with ZoomBrowser and HeliconFocus software. Scales on figures are in $\mathrm{mm}$.

The actual and predicted distributional maps were generated with DIVA-GIS bio-climatic software. Our model was based on 34 field records and met the requirements of the software (at least 5-10 records; Hernandez et al. 2006). The following environmental variables were used in the analysis: annual mean temperature, mean monthly temperature range, isothermality, temperature seasonality, maximum temperature of warmest month, minimum temperature of coldest month, annual temperature range, mean temperature of wettest quarter, mean temperature of driest quarter, mean temperature of warmest quarter, mean temperature of coldest quarter, annual precipitation, precipitation of wettest month, precipitation of driest month, precipitation seasonality, precipitation of wettest quarter, precipitation of driest quarter, precipitation of warmest quarter and precipitation of coldest quarter.

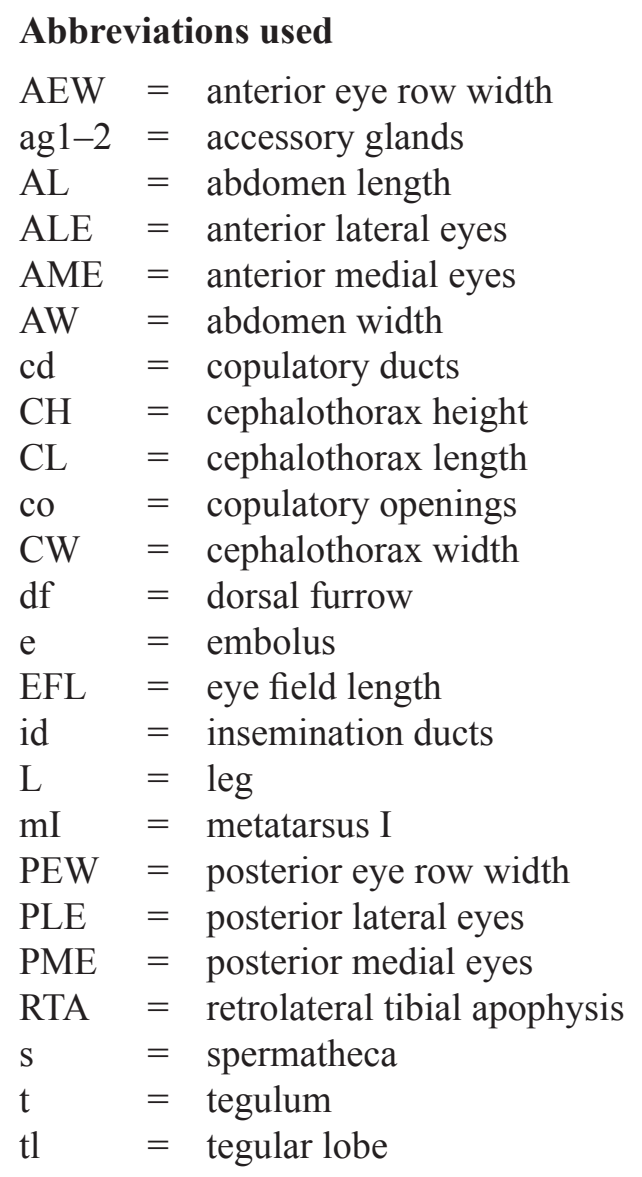

\section{Collections examined}

AMNH $=$ American Museum of Natural History, New York, USA

HNHM = Hungarian Natural History Museum, Budapest, Hungary 


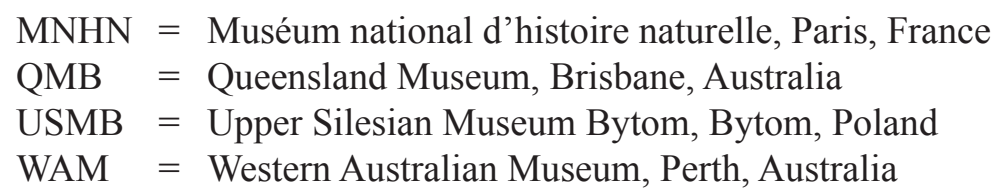

\section{Results}

Order Araneae Clerck, 1757

Family Salticidae Blackwall, 1841

Subfamily Salticinae Blackwall, 1841

Tribe Viciriini Simon, 1901 sensu Maddison 2015

Genus Corambis Simon, 1901

Corambis Simon, 1901: 605, 609, fig. 728.

Corambis - Berland 1924: 247. — Szüts 2002: 24-26, figs 1-4.

\section{Type species}

Hyctia insignipes Simon, 1880; by original designation.

\section{Diagnosis}

Spiders elongate, narrow and flat. Habitus similar to that of some other astioid genera (Holoplatys, Ocrisiona, Zebraplatys Żabka, 1992, Paraplatoides; Fig. 1), but first legs relatively heavier, chelicerae longer, palpal organ tegulum with a lobe, retrolateral tibial apophysis much larger and accessory glands (ag2) in female genitalia extremely long (Fig. 2). According to Maddison (2015) the genus is part of Tribe Viciriini within the Astioida clade (Maddison et al. 2008). Its closest relatives include other New Caledonian genera such as Rhondes, Penionomus and Trite Simton, 1885 (Fig. 1), and together they confirm local New Caledonian radiation.

\section{Description}

Spiders 3.5-13 mm long, thin, sexual dimorphism not distinctive (Figs 2-8). Cephalothorax almost twice as long as wide, uniformly flat, with no thoracic slope. Coloration in males rather uniformly dark, in females lighter with black eye surroundings. AME lenses twice diameter of ALE. PME tiny, closer to ALE than PLE, PLE equal to or smaller than ALE. Fovea behind PLE, slightly visible. Clypeus very narrow. Chelicerae unidentate, rather massive, maxillae elongate, sternum narrow and long. Abdomen very narrow and much longer than cephalothorax, sides almost parallel. Abdominal pattern with chevrons (C. insignipes, C. foeldvarii, C. jacknicholsoni sp. nov., C. logunovi sp. nov.) or dark spots (C. pantherae sp. nov.). Spinnerets and venter not distinctive. Both sexes with very strong first legs, in males with ventral brush of hairs on patella and tibiae. Ventral spines on tibiae in two rows 2-2-2, metatarsi with pairs of strong spines (Fig. 2B). Other legs delicate. Leg formula I-IV-II-III. Male palpal organ tegulum with posterior lobe, seminal duct not meandering, embolus short, fixed at top of tegulum and varying from hooked (C. insignipes, C. foeldvarii, C. jacknicholsoni sp. nov.) to wide and short (C. logunovi sp. nov.) (unknown in C. pantherae sp. nov.). Retrolateral tibial apophysis large and spatulate. Female copulatory openings close to epigastric furrow, far apart, oriented laterally (C. insignipes, C. jacknicholsoni sp. nov., C. logunovi sp. nov., C. pantherae sp. nov.) or posteriorly (C. foeldvarii). Spermathecae two-chambered (C. insignipes, C. logunovi sp. nov., C. pantherae sp. nov.) or three-chambered (C. foeldvarii, C. jacknicholsoni sp. nov.), located in central part of epigyne, strongly sclerotized. Main spermathecal chambers elongate, with two pairs of accessory glands, 


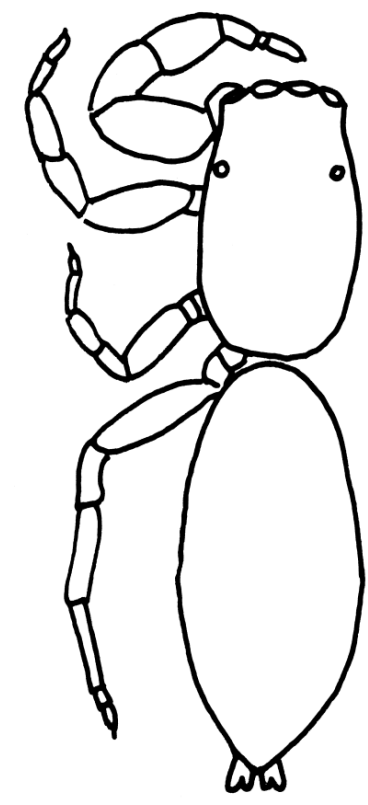

A

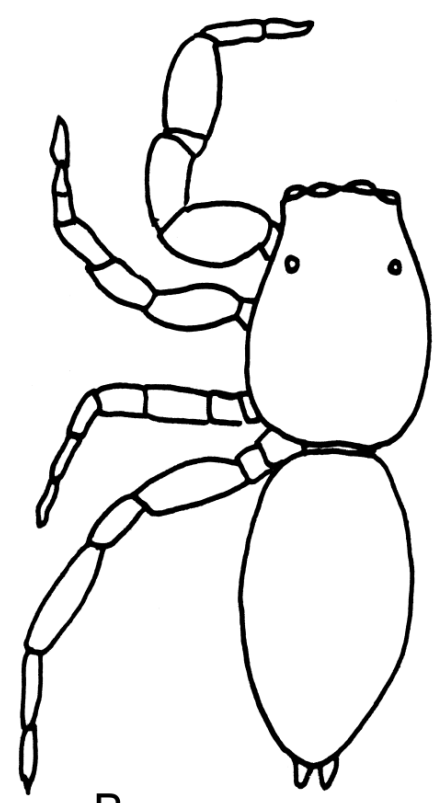

B

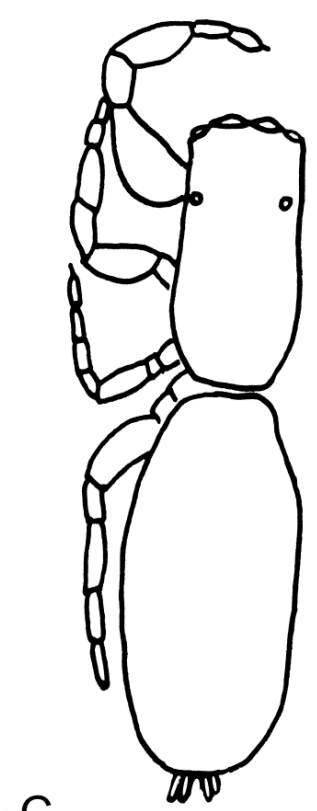

C
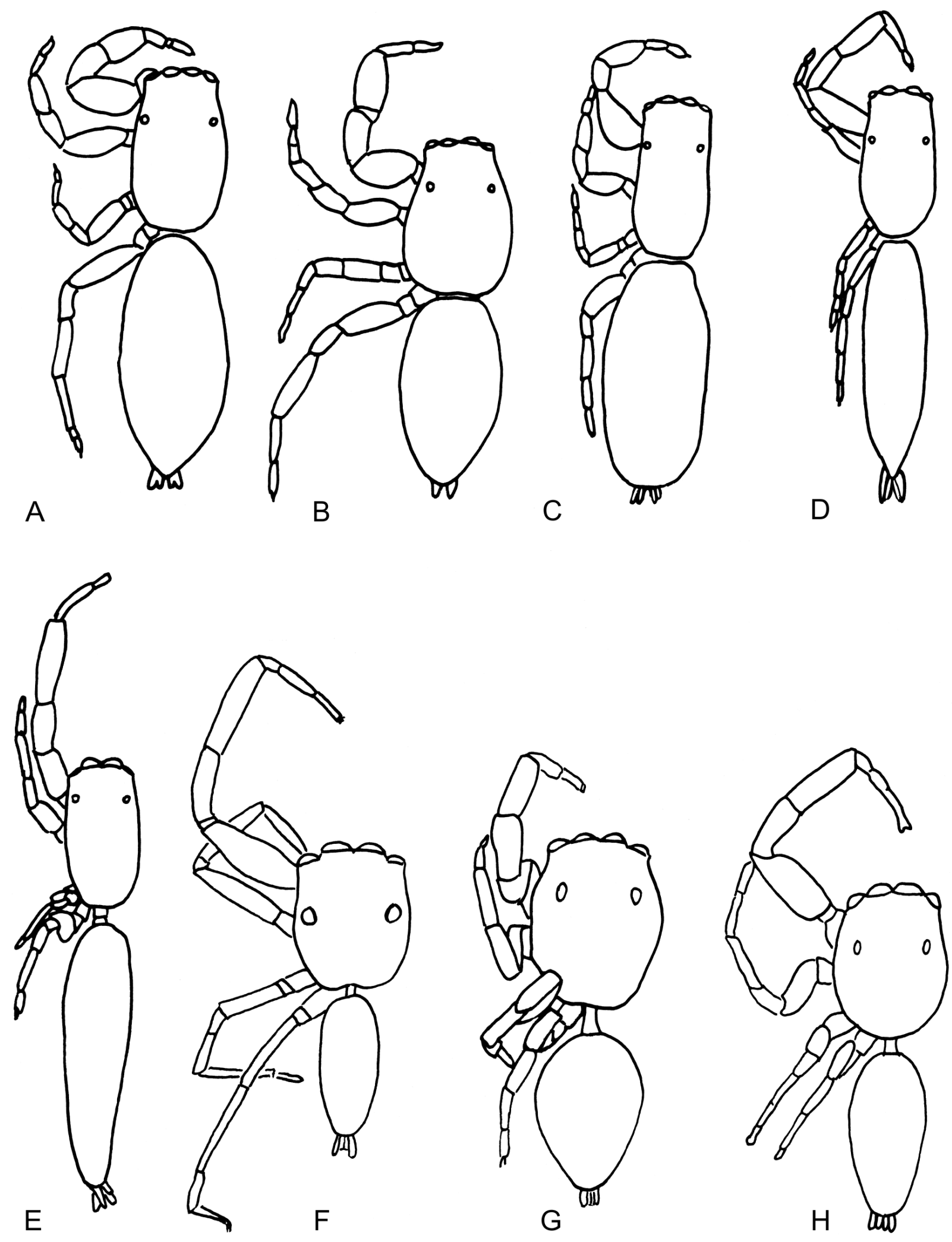

Fig. 1. Habitus of Corambis Simon, 1901 and related genera of Australasian Astioida. A. Holoplatys Simon, 1885. B. Ocrisiona Simon, 1901. C. Zebraplatys Żabka, 1992. D. Paraplatoides Żabka, 1992. E. Corambis Simon, 1901. F. Rhondes Simon, 1901. G. Trite Simon, 1885. H. Penionomus Simon, 1903. 
ag2 extremely long. Position of ag2 varying from lateral (C. insignipes, C.foeldvarii, C. jacknicholsoni sp. nov.), through postero-lateral (C. pantherae sp. nov.) to posterior (C. logunovi sp. nov.).

\section{Distribution}

All species of Corambis are exclusively distributed in $\mathrm{NC}$ and the neighboring Loyalty Islands (Figs 9-10), and are found in different types of forests. The endemic character of the genus is supported by its DIVA-GIS predicted distribution (Fig. 11). This modeling shows that Corambis is limited to NC.

\section{Corambis insignipes (Simon, 1880)}

Figs 2, 9

Hyctia insignipes Simon, 1880: 165.

Corambis insignipes - Simon 1901: 609, fig. 728. - Berland 1924: 247, figs 200-203. —Żabka 1988: 443, figs 59-61. — Szüts 2002: 26, figs 1-4, 6-9, 11-18. — Prószyński 2017: 26, fig. 11h.

\section{Material examined}

NEW CALEDONIA • 1 + , 1 juv.; Valle e Tionaka; 1911; Roux and Sarasin leg.; Berland det.; MNHN •

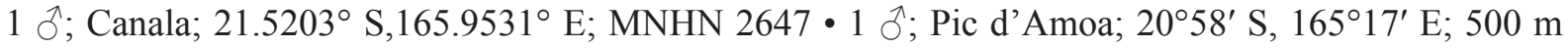
a.s.1.; 27 Nov. 2003-30 Jan. 2004; G. Monteith leg.; Malaise trap; QMB 11483 - 1 §; Aoupinié; $21^{\circ} 11^{\prime}$ S, $165^{\circ} 18^{\prime}$ E; 750 m a.s.l.; by hand; 2 May 2005; G.B. Monteith leg.; QMB 12281.

\section{Remarks}

The type species of this genus has been treated, described and illustrated on several occasions (see above).

Corambis foeldvarii Szüts, 2002

Figs 3, 9

Corambis foeldvarii Szüts, 2002: 29-31, figs 5, 10, 19-21.

\section{Diagnosis}

Differs from other species of the genus by its slightly pointed palpal tibial apophysis, posteriorly oriented female copulatory openings and the lateral location of its accessory glands (Fig. 3).

\section{Material examined}

\section{Paratype}

NEW CALEDONIA • 1 \%; Maré; $21.49309^{\circ}$ S, $167.9967^{\circ}$ E; HNHM 2014a.

\section{Other material}

NEW CALEDONIA • 1 đ, 1 q, 1 juv.; Farino; 21.66399 S, $165.77493^{\circ}$ E; 25 Aug. 1982; HNHM

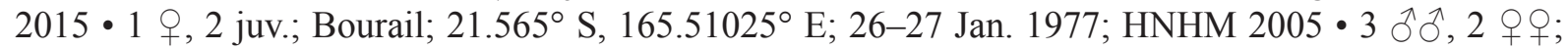

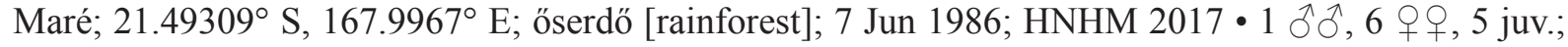
same collection data as for preceding; HNHM 2007 • 2 ô $^{\top}$; Rivière Bleue; $22.1051^{\circ} \mathrm{S}, 166.70^{\circ} \mathrm{E}$; 21 Oct. 1992; Chazeau, Guilbert and Bonnet de Larbogne leg.; dense forest; fogging; MNHN 1 , , 1 juv.; Pindai; 21.35 S, $164.96666^{\circ}$ E; 5 Jan. 1993; Chazeau, Giulbert and Bonnet de Larbogne det.; sclerophyllic forest; fogging; MNHN • 1 क; Col d'Amieu; $21^{\circ} 35^{\prime} \mathrm{S}, 165^{\circ} 48^{\prime} \mathrm{E}$; $440-470 \mathrm{~m}$ a.s.l.; $7 \mathrm{Jan}$.

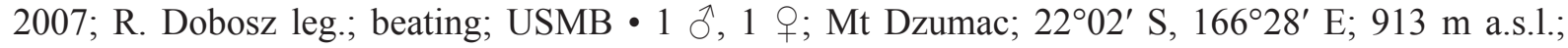


29 Dec. 2006; R. Dobosz leg.; USMB • 1 ơ; Yahoué; $22.12^{\circ}$ S, $166.30^{\circ}$ E; 100 m a.s.1.; Nov 1986; N.L.H. Kraus leg.; AMNH 1 o ${ }^{\wedge}, 1$ juv.; Houte Riviere Blue track to La Trauchae; $22^{\circ} 06^{\prime}$ S, $166^{\circ} 38^{\prime}$ E; 300 m a.s.1.; 21 Dec. 2006; R. Dobosz leg.; USMB • 1 क; Cap Ndoua; 22²3' S, 16655’ E; 50 m a.s.1.; 29 Nov. 2004; S.G. Write leg.; rainforest; sweeping; WAM 11809 • 1 क ; Cap Ndoua; 22²3' S, $166^{\circ} 55^{\prime}$ E; 50 m a.s.1.; 28-29 Nov. 2004; C. Burwell and S. Write leg.; rainforest; yellow pan; WAM 11808.
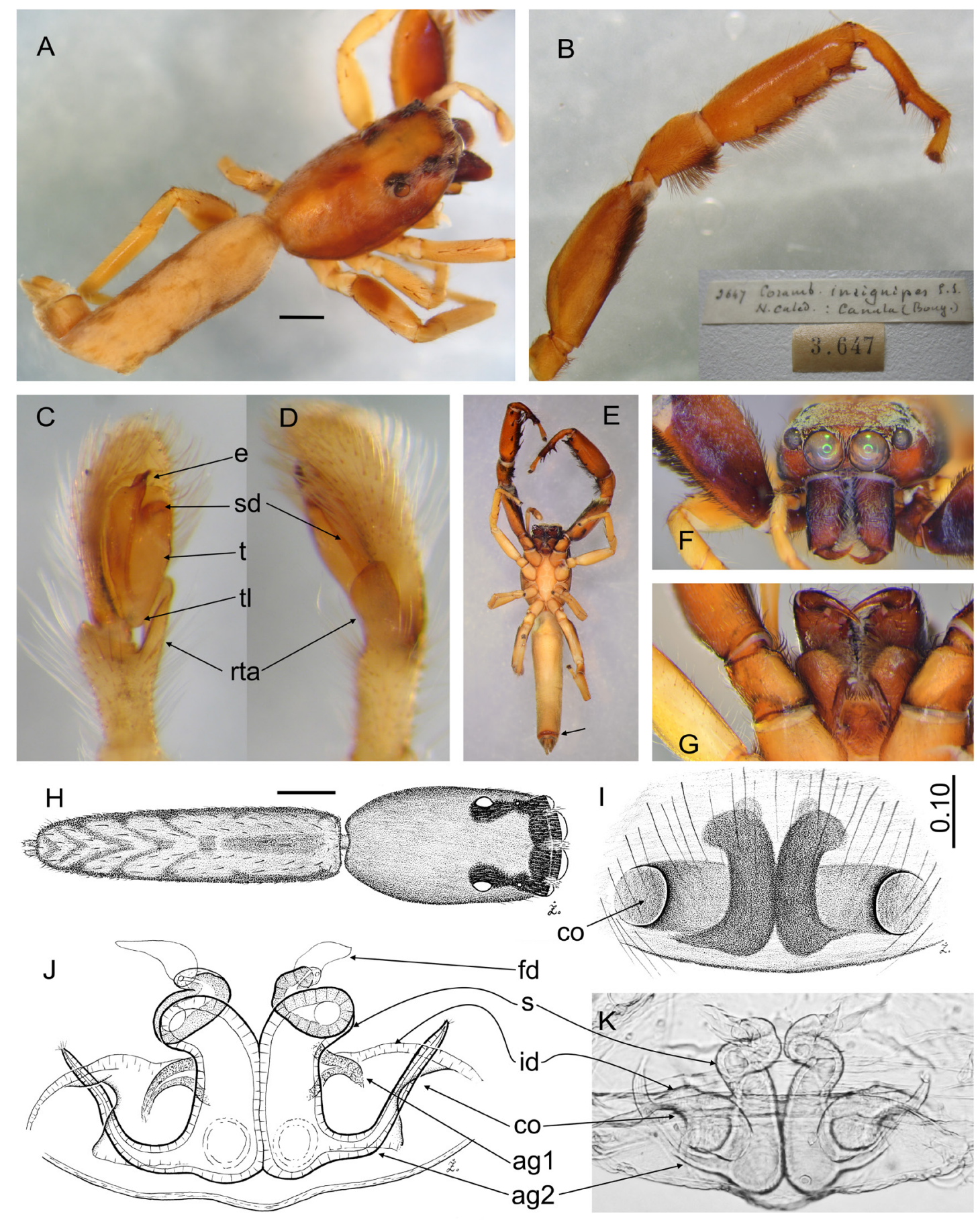

Fig. 2. Corambis insignipes (Simon, 1880). A-D. MNHN 2647. E-G. QMB 11483. H-K. Vallee

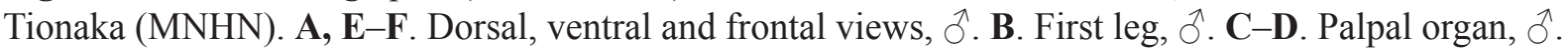

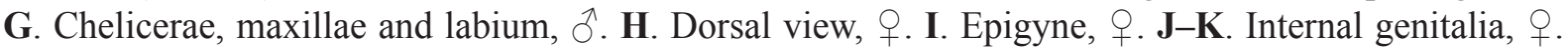
Scale bars: $\mathrm{A}, \mathrm{H}=1 \mathrm{~mm}$. 


\section{Description}

Female (first description)

Cephalothorax reddish-brown, sides brown, along central part with longitudinal darker line. Hairiness delicate, light grey. Abdomen beige with delicate chevrons, sides contrasting brown. Clypeus and chelicerae brown, maxillae and labium brownish, sternum contrastingly lighter, venter beige. First legs
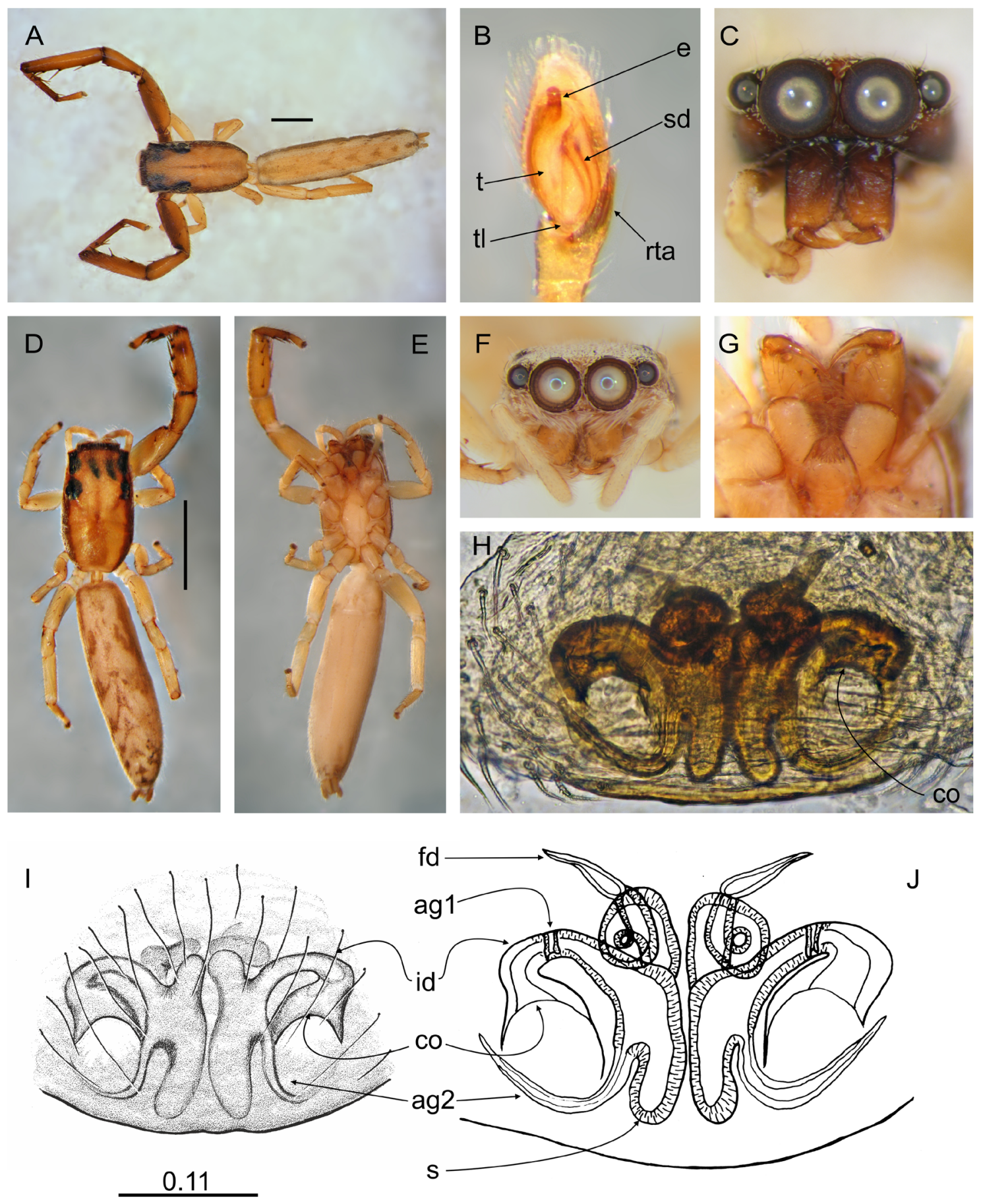

Fig. 3. Corambis foeldvarii Szüts, 2002. A-C. Mt Dzumac (USMB). D-J. Paratype (HNHM 2014a).

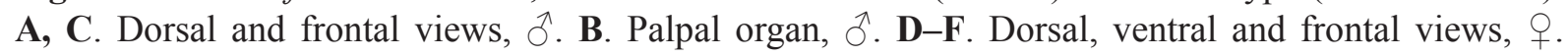
G. Chelicerae, maxillae and labium, $q$. H, J. Internal genitalia, + . I. Epigyne, $\uparrow$. Scale bars: A, D = $1 \mathrm{~mm}$. 
brownish, patellae with dorsal fringe. Other legs light grey, delicate, not distinctive. Epigyne poorly sclerotized, copulatory openings oriented posteriorly. In comparison to other species, insemination ducts wide and longest. Spermathecae two-chambered (Fig. 3H-J). Dimensions: CL 1.40, CW 0.80, CH 0.36, EFL 0.58, AEW 0.69, PEW 0.69, AL 2.37, AW 0.62.

Corambis jacknicholsoni sp. nov.

urn:1sid:zoobank.org:act:4210054D-94C4-4169-81A7-56B035242EED

Figs $4-5,10$

\section{Diagnosis}

Differs from other species of the genus by its hook-like embolus (Fig. 4E-F) and the lateral location of ag2 in females (Fig. 5G).

\section{Etymology}

This beautiful spider is named for Mr. Jack Nicholson, the great American actor, three times Oscar winner.

\section{Material examined}

\section{Holotype}

NEW CALEDONIA • ${ }^{\wedge}$; Plaine du champ de Bataille; $22^{\circ} 18^{\prime}$ S, $166^{\circ} 44^{\prime}$ E; 43 m a.s.1.; 17 Dec. 2006; R. Dobosz leg.; MNHN (previously USMB 9).

\section{Paratypes}

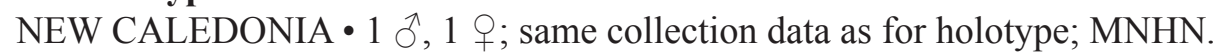

\section{Other material}

NEW CALEDONIA • 1 q, 1 juv.; Noumea, Anse vata; $22.3004763^{\circ} \mathrm{S}, 166.44329^{\circ}$ E; $1-4$ Apr. 1985 ; A.D. Austin leg.; low vegetation; sweeping; WAM T47813 • 1 क ; Yahoué; $22.12^{\circ} \mathrm{S}, 166.30^{\circ} \mathrm{E} ; 100 \mathrm{~m}$ a.s.1.; Nov 1986; N.L.H. Kraus leg.; AMNH • 1 क; Île des Pins; $22.615^{\circ}$ S, $167.48167^{\circ}$ E; 1 Oct. 1977; Gadji e kereg; HNHM 2009 • 1 क , 2 juv.; Pindai; $21.35^{\circ}$ S, $164.966667^{\circ}$ E; 5 Jan. 1993; Chazeau,

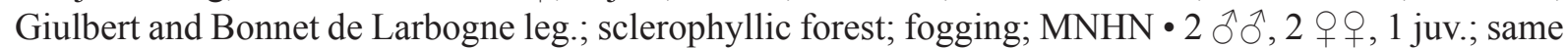
collection data as for preceding; $14 \mathrm{Apr}$. 1993; MNHN • 1 , 1 juv.; same collection data as for preceding;

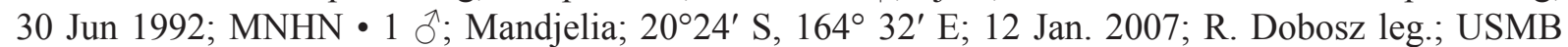
- 1 ○; Gue de la Purina; $22.027681^{\circ}$ S, $166.732878^{\circ}$ E; 22 Dec. 2006; R. Dobosz leg.; beating; USMB - 1 o; Pic du Grand Kaori; $22^{\circ} 17^{\prime}$ S, $166^{\circ} 59^{\prime}$ E; 239 m a.s.1.; 26 Dec. 2006; R. Dobosz leg.; USMB

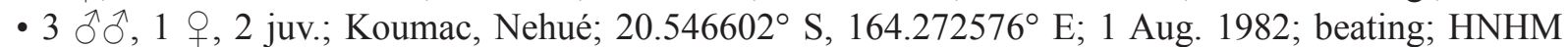
- 1 ○; Riviere Bleue; $22.1051^{\circ} \mathrm{S}, 166.70^{\circ} \mathrm{E}$; 16 July 1992; Chazeau, Guilbert and Bonnet de Larbogne leg.; dense forest; P6 [Parcel 6?]; fogging; MNHN -1 d ; same collection data as for preceding; 21 Oct. 1992; MNHN • 1 ; ; same collection data as for preceding; 21 Dec. 1992; MNHN • 2 q 9 ; same collection data as for preceding; 20 Jan. 1993; MNHN • 1 क , 1 juv.; Wao Umi (Ichamba Forest); $21^{\circ} \mathrm{S}$, $165^{\circ} 15^{\prime}$ E; 390 m a.s.1.; 15 Jan. 2007; R. Dobosz leg.; USMB.

\section{Description}

\section{Male}

Cephalothorax centrally beige, sides brown. Abdomen very narrow and elongate, along central part beige with darker chevrons. Sides dirty brown with longitudinal indentation. Venter beige with two darker lines. Clypeus brownish. Chelicerae, maxillae and labium dirty orange. Sternum contrasting light. First legs dirty brown on sides, dorsally and ventrally lighter. Patellae with fringes of hairs. Other 
legs yellowish, delicate. Pedipalps light yellowish. Tegulum ovoid with posterior lobe, embolus hooklike, tibial apophysis large, spatulate with dorsal furrow (Fig. 4E-G). Dimensions: CL 2.69, CW 1.56, CH 0.66, EFL 1.01, AEW 1.24, PEW 1.23, AL 4.15, AW 1.05.
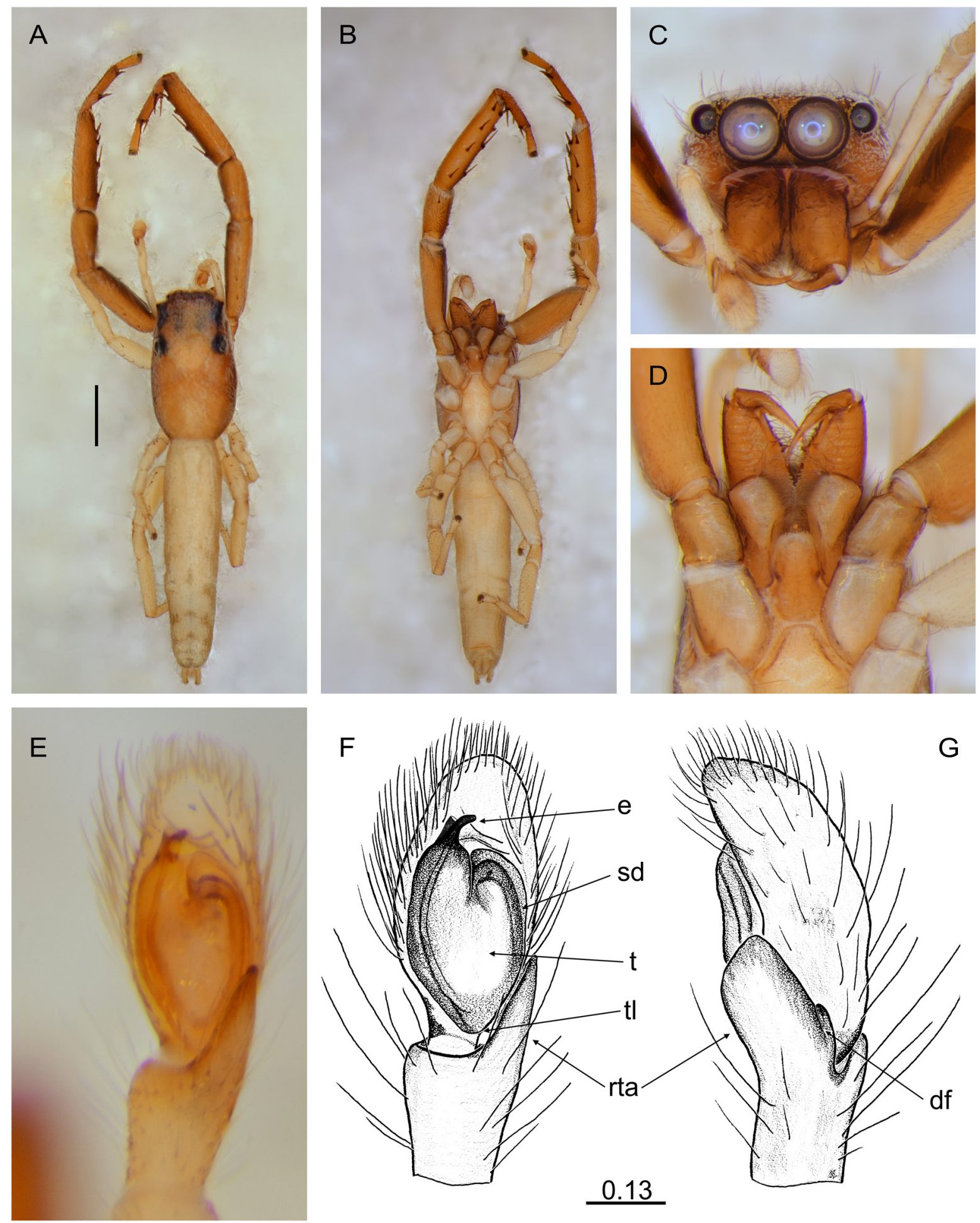

Fig. 4. Corambis jacknicholsoni sp. nov., holotype, ổ (MNHN). A-C. Dorsal, ventral and frontal views. D. Chelicerae, maxillae and labium. E-G. Palpal organ. Scale bar: A=1 mm. 


\section{Female}

Cephalothorax along central part yellowish-grey, sides darker. Anterior and median eye surroundings brownish, PLE black. Abdomen beige, with delicate chevrons. Clypeus orange-grey, chelicerae light brown, pedipalps light grey, maxillae and labium grey. Sternum contrastingly light, venter beige. First legs dirty orange, patellae with no fringe. Other legs yellowish, delicate. Epigyne and internal genitalia as in Fig. 5F-H. Copulatory openings oriented laterally, insemination ducts shorter and joining spermathecae in their posterior parts (close to epigastric furrow). Spermathecae three-chambered. Dimensions: CL 2.22, CW 1.39, CH 0.61, EFL 0.92, AEW 1.08, PEW 1.07, AL 3.94, AW 1.10.
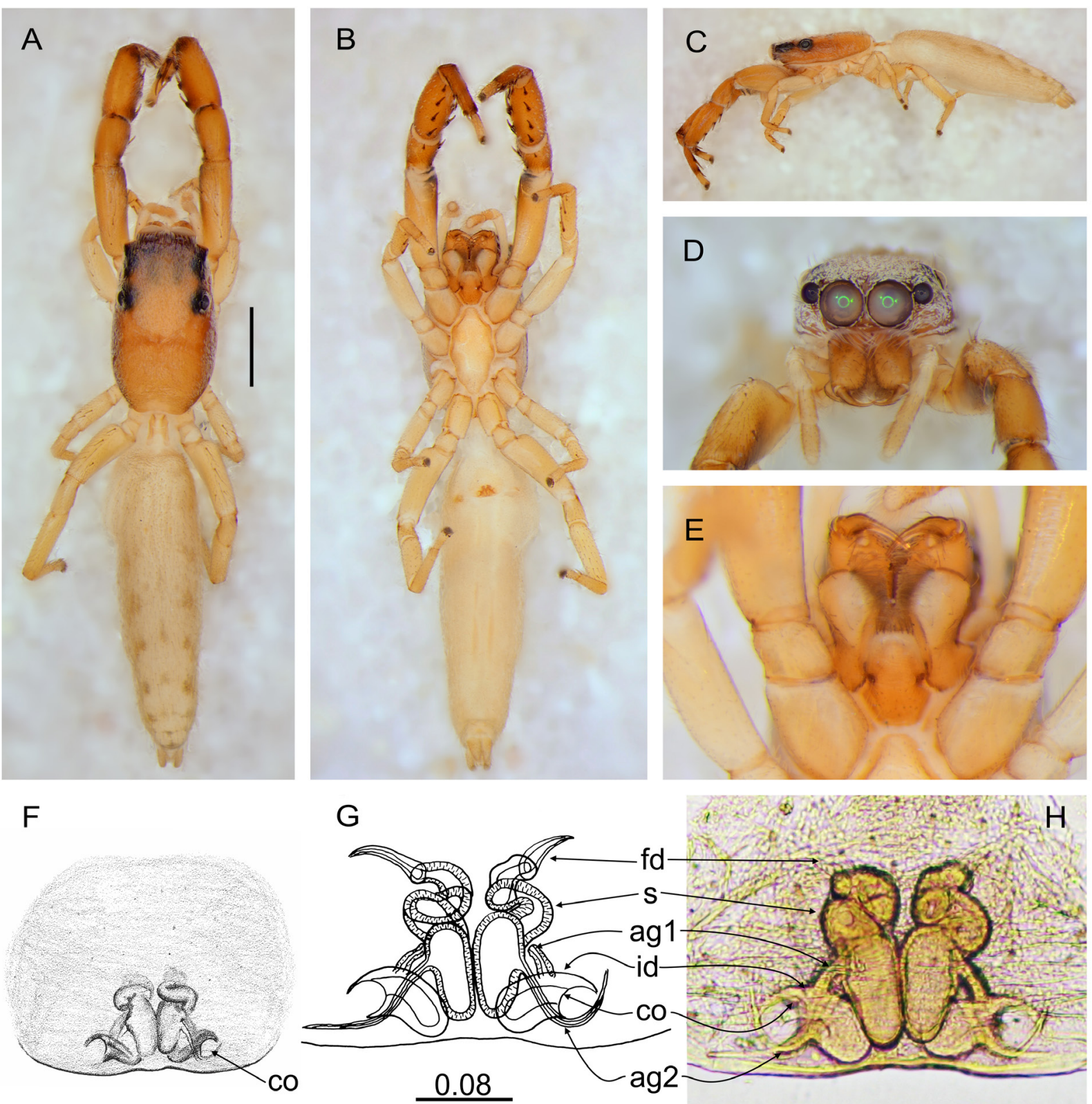

Fig. 5. Corambis jacknicholsoni sp. nov., paratype, $q$ (MNHN). A-D. Dorsal, ventral, lateral and frontal views. E. Chelicerae, maxillae and labium. F. Epigyne. G-H. Internal genitalia. Scale bar: A=1 mm. 
Corambis logunovi sp. nov.

urn:1sid:zoobank.org:act:0766EFA2-3BE9-4896-AD4E-C19035E653B3

Figs $6-7,9$

\section{Diagnosis}

Differs from other species of the genus by its darker coloration, legs with no fringe, longer chelicerae, and much wider and heavier embolus (Fig. 6E-F). Copulatory openings oriented antero-laterally, accessory glands situated posteriorly on spermathecae (Fig. 7G).
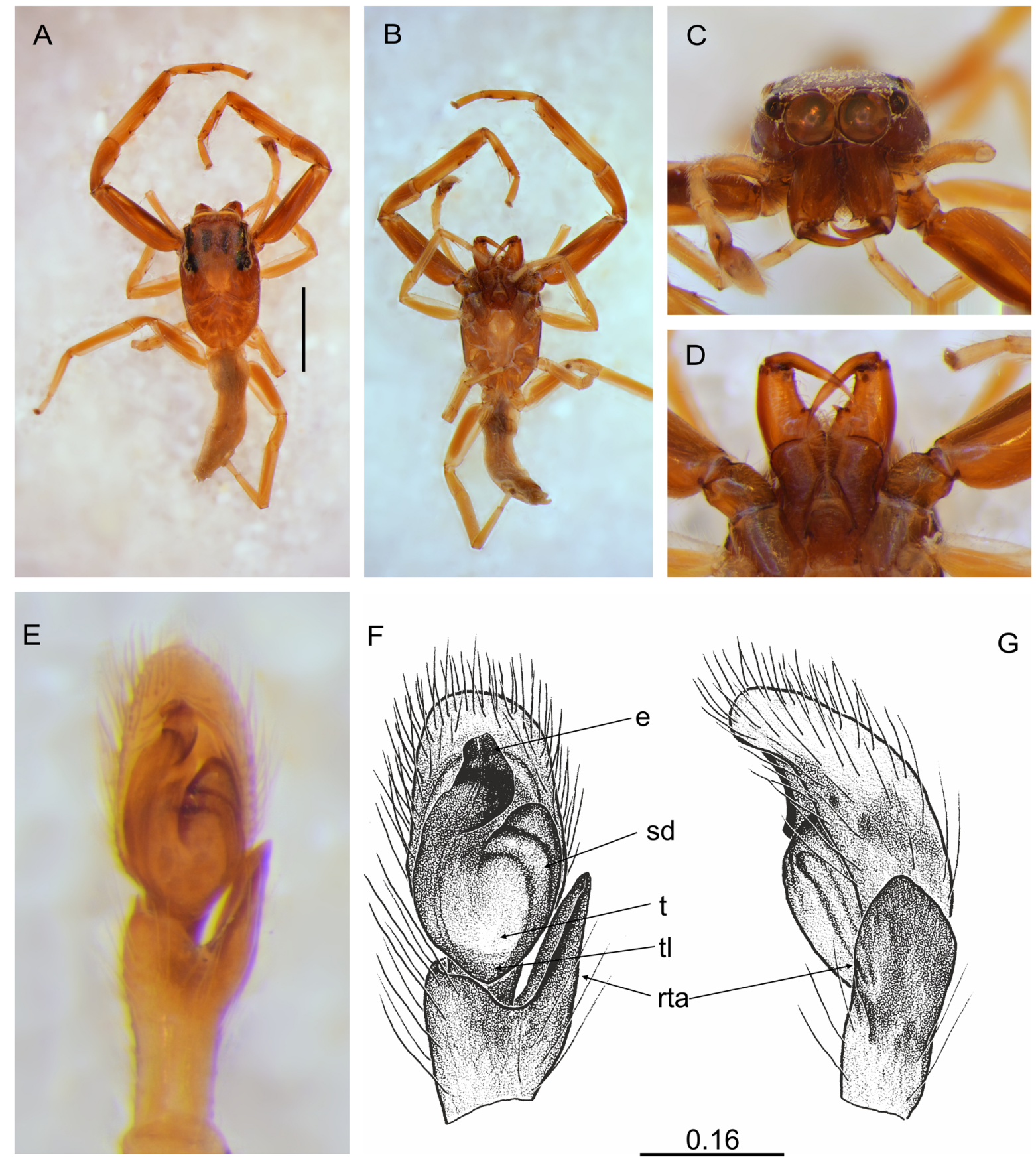

Fig. 6. Corambis logunovi sp. nov., holotype, ồ (HNHM 2014). A-C. Dorsal, ventral and frontal views. D. Chelicerae, maxillae and labium. E-G. Palpal organ. Scale bar: A = $1 \mathrm{~mm}$. 


\section{Etymology}

This species is named for Dr. Dmitri Logunov, a distinctive Russian arachnologist (now at the University of Manchester), a friend of ours.
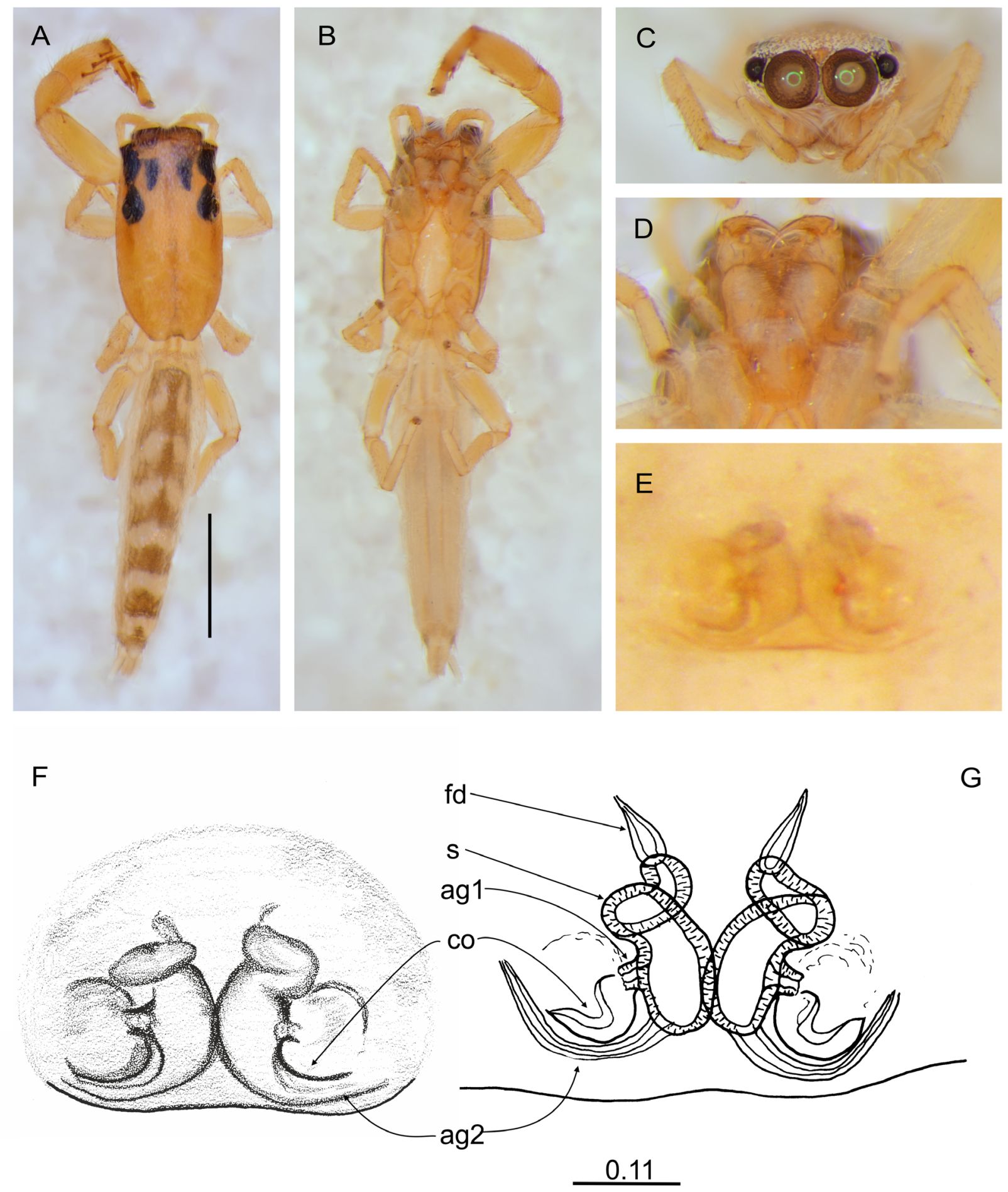

Fig. 7. Corambis logunovi sp. nov., paratype, $q$ (HNHM). A-C. Dorsal, ventral and frontal views. D. Chelicerae, maxillae and labium. E-F. Epigyne. G. Internal genitalia. Scale bar: A=1 mm. 


\section{Material examined}

Holotype

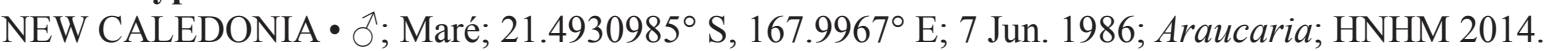

Paratype

NEW CALEDONIA • 1 ; ; same collection data as for holotype; HNHM.

\section{Description}

Male

Cephalothorax chestnut-brown, glossy, slightly darker on eye field, with delicate light grey hairs. Abdomen brown, darker along median part. Spinnerets brown, not distinctive. Clypeus brown, very narrow. Chelicerae, maxillae and labium brown. Sternum slightly lighter. Venter brown. First legs brown, distally increasingly lighter. Other legs delicate grayish-orange. Palpal organ as in Fig. 6E-F, tegular lobe indisctinctive, embolus very wide, tibial apophysis spatulate. Dimensions: CL 1.52, CW 0.98, CH 0.62, EFL 0.59, AEW 0.79, PEW 0.74.

\section{Female}

Body very long and slender. Cephalothorax pale-orange, eye surroundings black with light grey hairs, lower margin darker. Eye field with two dark spots. Abdomen light grey with darker chevron pattern. Spinnerets light grey. Clypeus orange-grey with lighter hairs, very narrow. Chelicerae pale, orange-grey. Pedipalps yellowish. Maxillae and labium pale orange-grey, sternum light yellowish with darker narrow margin. Venter light grey with two longitudinal lines. All legs pale grayish-orange. First legs much more robust, but podomeres much shorter than in males. Other legs very delicate. Epigyne and internal genitalia as in Fig. 5E-G. Copulatory openings oriented antero-laterally, insemination ducts very short and joining spermathecae in their posterior parts. Spermathecae two-chambered. Dimensions: CL 1.58, CW 0.86, CH 0.38, EFL 0.63, AEW 0.78, PEW 0.71, AL 2.42, AW 0.55.

Corambis pantherae sp. nov. urn:1sid:zoobank.org:act:1BBF9ECA-338A-4508-A7F6-53C2EFED28E1

Figs 8,10

\section{Diagnosis}

Differs from other species of the genus by its relatively wider cephalothorax and spotted abdominal pattern. Copulatory openings oriented laterally, ag2 situated postero-laterally (Fig. 8).

\section{Etymology}

This species is named for its abdominal pattern.

\section{Material examined}

Holotype

NEW CALEDONIA • $q$; Mt. Panié; $20.58833^{\circ}$ S, $164.77083^{\circ}$ E; 1300-1600 m a.s.1.; 15 May 1984; G. Monteith and D. Cook leg.; QMB S35653.

\section{Description}

\section{Female}

Cephalothorax dark brown, with numerous light grey hairs. Eye surroundings black. Between cephalic and thoracic part delicate depression, just behind eye field. Clypeus dark brown with light grey long hairs. Chelicerae, maxillae and labium brown. Sternum dirty orange brown with darker margin. First 
legs dirty light brown, with very strong spines on tibiae and metatarsi. Other legs dirty-orange. Abdomen dirty-orange with distinctive dark spots. Spinnerets grey. Venter light grey, distally darker with two longitudinal lines. Internal genitalia similar to those of $C$. insignipes, copulatory openings oriented laterally, insemination ducts short, joinings posterior parts of spermathecae. Spermathecae relatively smaller than in C. insignipes, two-chambered (Fig. 8E-G). Dimensions: CL 4.50, CW 3.09, CH 1.29, EFL 1.67, AEW 2.40, PEW 2.33, AL 7.64, AW 2.21.

Male

Unknown.

\section{Discussion}

For a long time the salticids of New Caledonia have been discussed in terms of Gondwanan origin and heritage; however, the timing of NC separation (80 mya), its subsequent submergences and the predicted
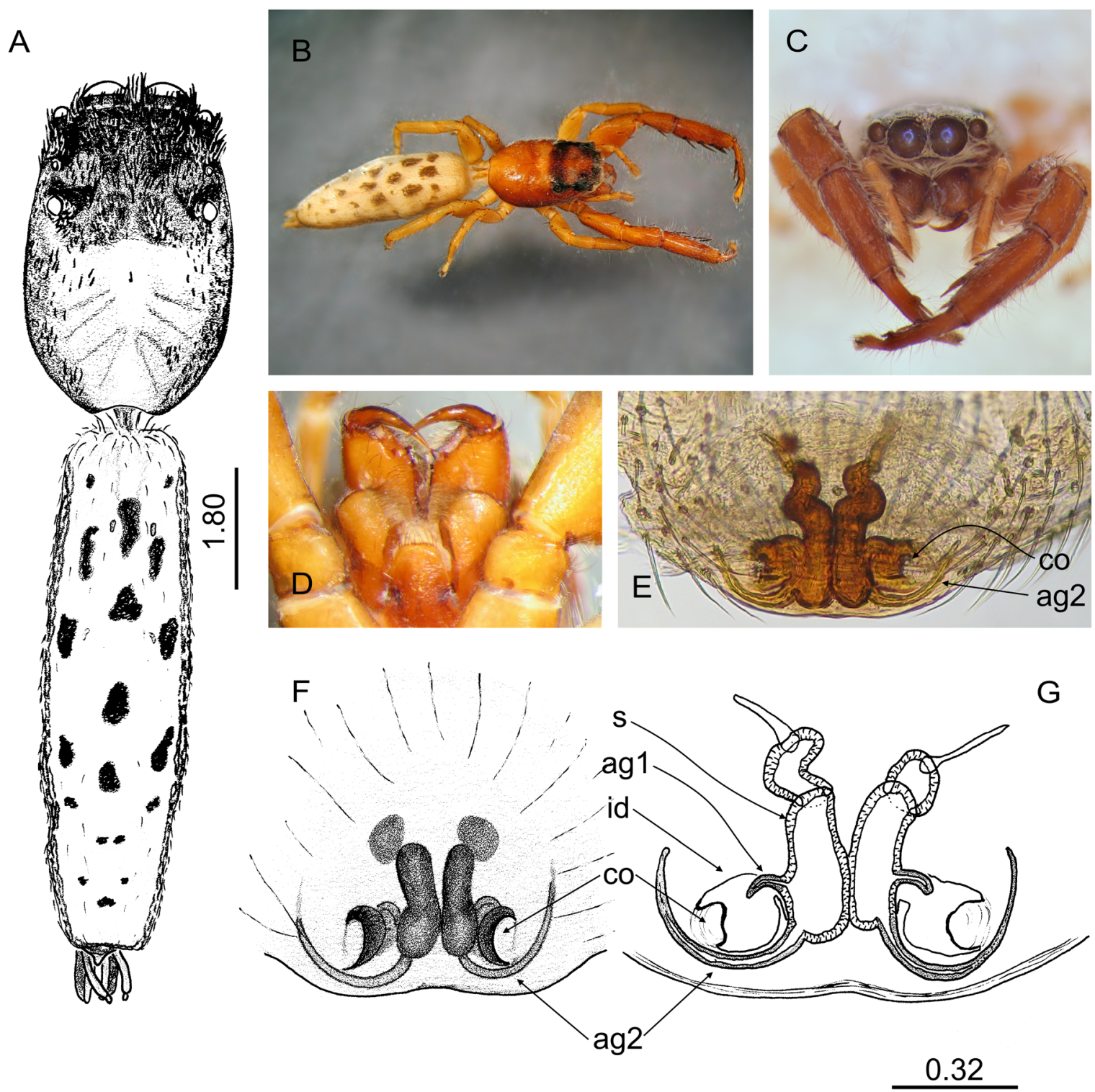

Fig. 8. Corambis pantherae sp. nov., holotype, ${ }$ (QMB S35653). A-C. Dorsal and frontal views. D. Chelicerae, maxillae and labium. E, G. Internal genitalia. F. Epigyne. 


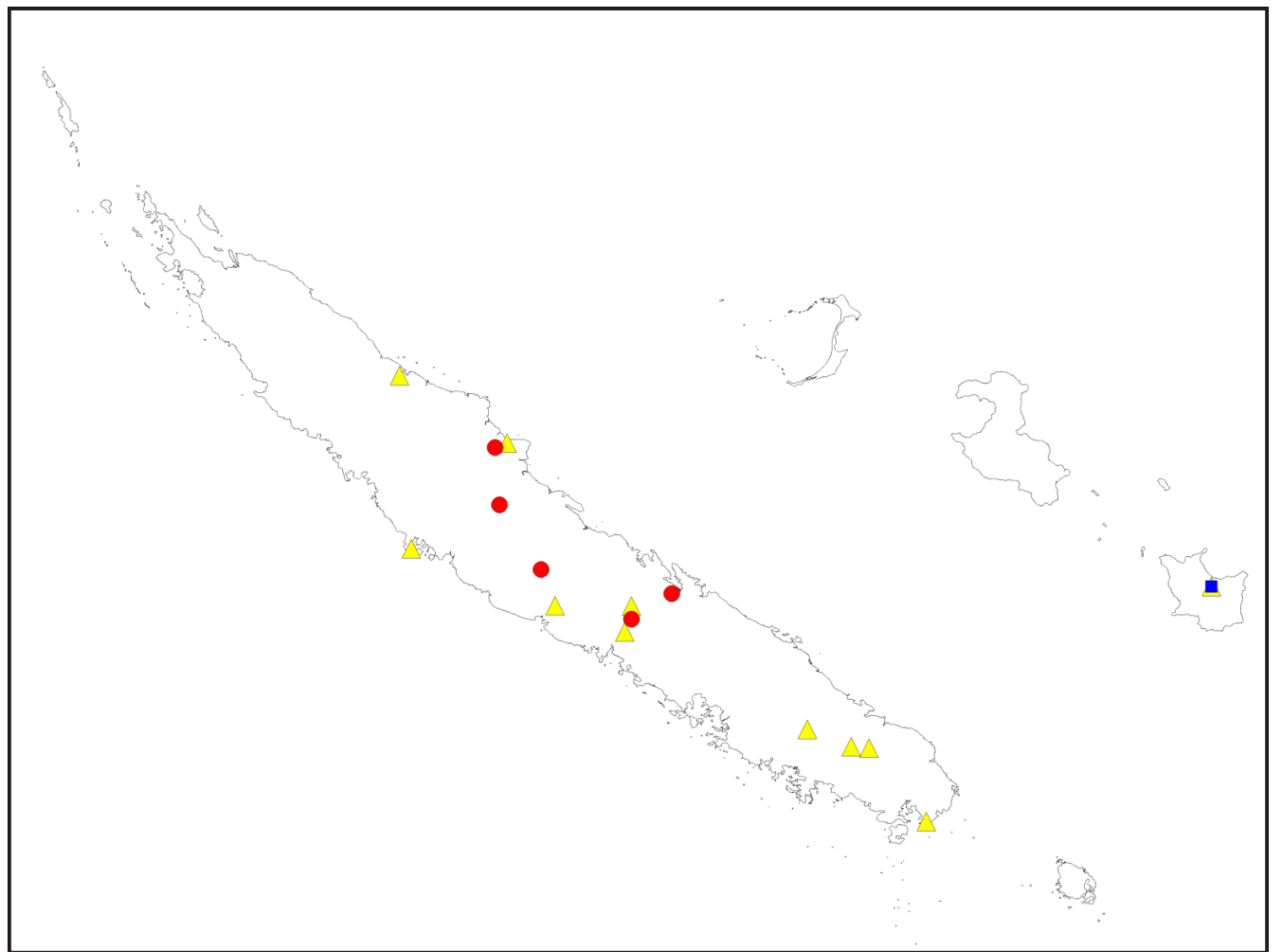

Fig. 9. Recorded localities of C. insignipes (Simon, 1880) (circle), C. foeldvarii Szüts, 2002 (triangle) and C. logunovi sp. nov. (square) in New Caledonia and the Loyalty Islands.

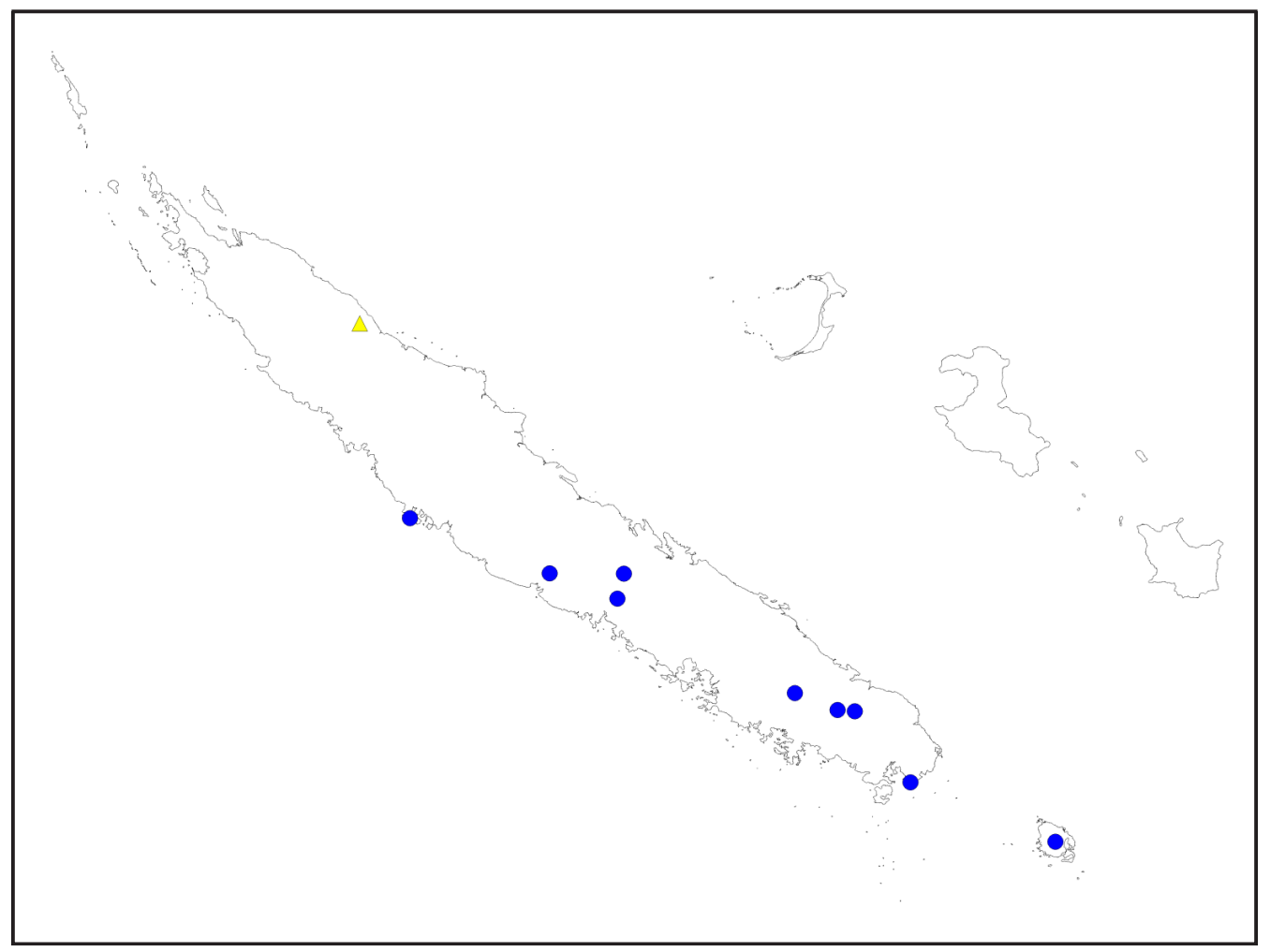

Fig. 10. Recorded localities of C. jacknicholsoni sp. nov. (circle) and C. pantherae sp. nov. (triangle) in New Caledonia and the Loyalty Islands. 


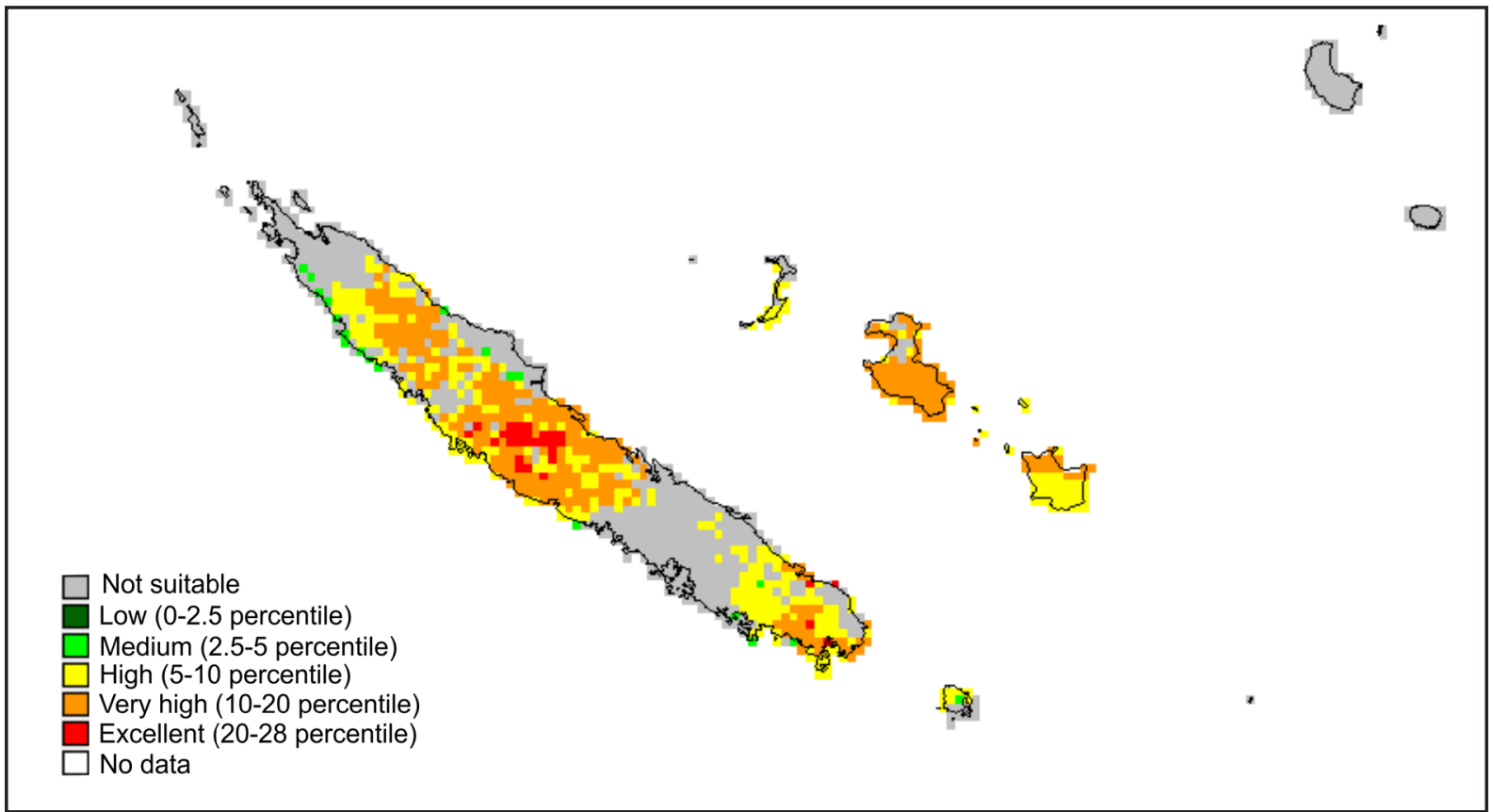

Fig. 11. Predicted distribution of Corambis Simon, 1901.

age of Salticidae ( 50 my) make the Gondwanan hypothesis very unlikely. Recent geological studies have revealed that $\mathrm{NC}$ was part of the Zealandia land mass, together with New Zealand, Norfolk Island and Lord Howe Island. NC only emerged in the Oligocene, some 37 mya (e.g., Cluzel et al. 2012; Campbell et al. 2012). Under such a scenario the fauna of NC must be much younger than thought before, and its diversity and endemism seem to be the result of 1) later (post-Gondwanan) colonization and dispersal from Australia, and migration between NC, Lord Howe Island and New Zealand, and 2) subsequent radiation in situ. Such a view is strongly supported by the molecular data on the relationships of the Australasian salticid taxa (Maddison et al. 2008; Maddison 2015) and by the case of Trite described earlier (Patoleta \& Żabka 2017).

Furthermore, the endemism of Corambis and its relatives (Lystrocteisa, Penionomus, Rhondes, and Rogmocrypta) seems to be the result of quite recent New Caledonian radiation. The timing of this phenomenon is as yet unknown, but judging from the case of Trite and estimates for Penionomus (Bodner \& Maddison 2012; Patoleta \& Żabka 2017) the radiation may have begun some 10 mya. The problem can be solved by using fresh material and molecular data (molecular clock).

\section{Acknowledgements}

We thank the following persons and friends for providing the material for this study: Prof. Norman Platnick (AMNH), Dr Robert Raven (QMB), Dr Tamas Szüts (HNHM), Dr Christine Rollard (MNHN), Dr Roland Dobosz (USMB) and Julianne Margaret Waldock (WAM). This research was supported by the Siedlce University of Natural Sciences and Humanities, Faculty of Natural Sciences (project 18/91/S).

\section{References}

Berland L. 1924. Araignées de la Nouvelle Calédonie et des Îles Loyalty. In: Sarasin F. \& Roux J. (eds) Nova Caledonia. Zoologie 3: 159-255.

Bodner M.R. \& Maddison W.P. 2012. The biogeography and age of salticid spider radiations (Araneae: Salticidae). Molecular Phylogenetics and Evolution 65: 213-240.

https://doi.org/10.1016/j.ympev.2012.06.005 
Campbell H., MalahoffA., Browne G., Graham I. \& Sutherland R. 2012. New Zealand geology. Episodes 35 (1): 57-71.

Cluzel D., Maurizot P., Collot J. \& Sevin B. 2012. An outline of the geology of New Caledonia; from Permian-Mesozoic Southeast Gondwanaland active margin to Cenozoic obduction and supergene evolution. Episodes 35 (1): 72-86.

Grandcolas P., Murienne J., Robillard T., Desutter-Grandcolas L., Jourdan H., Guilbert E. \& Deharveng L. 2008. New Caledonia: a very old Darwinian island? Philosophical Transactions of the Royal Society of London B 363 (1508): 3309-3317. https://doi.org/10.1098/rstb.2008.0122

Haeds M. 2010. The endemic plant families and the palms of New Caledonia: a biogeographical analysis. Journal of Biogeography 37: 1239-1250. https://doi.org/10.1111/j.1365-2699.2010.02292.x

Hernandez P.A., Graham C.H., Master L.L. \& Albert D.L. 2006. The effect of sample size and species characteristics on performance of different species distribution modeling methods. Ecography 29: e773785. https://doi.org/10.1111/j.0906-7590.2006.04700.x

Maddison W.P. 2015. A phylogenetic classification of jumping spiders (Araneae: Salticidae). Journal of Arachnology 43: 231-292. https://doi.org/10.1636/arac-43-03-231-292

Maddison W.P., Bodner M.R. \& Needham K.M. 2008. Salticid spider phylogeny revisited, with the discovery of a large Australasian clade (Araneae: Salticidae). Zootaxa 1893: 49-64.

https://doi.org/10.11646/zootaxa.1893.1.3

Patoleta B. 2002. Salticidae of New Caledonia and Fidji. PhD Thesis. Katedra Zoologii, AP, Siedlce, Poland.

Patoleta B. 2017. Salticidae (Arachnida: Araneae) Wysp poludniowo-zachodniego Pacyfiku Pochodzenie i Ocena różnorodności Fauny [Salticidae (Arachnida: Araneae) of SW Pacific Islands - Origin and Diversity of Fauna]. Wydawnictwo Uniwersytetu Przyrodniczo-Humanistycznego w Siedlcach, Siedlce, Poland.

Patoleta B. \& Żabka M. 2017. A new species of Trite Simon, 1885 (Araneae: Salticidae) from New Zealand, with remarks on Trite relationships and radiation. PeerJ 5: e3463. https://doi.org/10.7717/peerj.3463

Platnick N.I. 1993. The araneomorph spider fauna of New Caledonia. Biodiversity Letters 1 (3/4): 102106. https://doi.org/10.2307/2999754

Platnick N.I. \& Forster R.R. 1989. A revision of the temperate South American and Australasian spiders of the family Anapidae (Araneae, Araneoidea). Bulletin of the American Museum of Natural History 190: $1-139$.

Platnick N.I. \& Forster R.R. 1993. A revision of the New Caledonian spider genus Bradystichus (Araneae, Lycosoidea). American Museum Novitates 3075: 1-14.

Prószyński J. 2017. Pragmatic classification of the world's Salticidae (Araneae). Ecologica Montenegrina 12: $1-133$.

Raven R.J. 1994. Mygalomorph spiders of the Barychelidae in Australia and the western Pacific. Memoirs of the Queensland Museum 35: 291-706.

Simon E. 1880. Matériaux pour servir à une faune arachnologique de la Nouvelle Calédonie. Annales de la Société entomologique de Belgique 23 (C.R.): 164-175.

Simon E. 1901. Histoire naturelle des Araignées. Paris 2: 381-668.

https://doi.org/10.5962/bhl.title.51973 
Szüts T. 2002. Remarks on the genus Corambis Simon, 1901 (Araneae: Salticidae). Folia Entomologica Hungarica 63: 23-31.

WSC. 2019. World Spider Catalog. Version 20.5. Natural History Museum Bern.

https://doi.org/10.24436/2

Wulff A.S., Hollingsworth P.M., Ahrends A., Jaffré T., Veillon J-M., L’Huillier J. \& Fogliani B. 2013. Conservation priorities in a biodiversity hotspot: Analysis of narrow endemic plant species in New Caledonia. PLoS One 8 (9): e73371. https://doi.org/10.1371/journal.pone.0073371

Żabka M. 1988. Salticidae (Araneae) of Oriental, Australian and Pacific regions, III. Annales Zoologici 41: 421-479.

Manuscript received: 19 July 2019

Manuscript accepted: 2 September 2019

Published on: 19 November 2019

Topic editor: Rudy Jocqué

Desk editor: Danny Eibye-Jacobsen

Printed versions of all papers are also deposited in the libraries of the institutes that are members of the EJT consortium: Muséum national d'histoire naturelle, Paris, France; Meise Botanic Garden, Belgium; Royal Museum for Central Africa, Tervuren, Belgium; Royal Belgian Institute of Natural Sciences, Brussels, Belgium; Natural History Museum of Denmark, Copenhagen, Denmark; Naturalis Biodiversity Center, Leiden, the Netherlands; Museo Nacional de Ciencias Naturales-CSIC, Madrid, Spain; Real Jardín Botánico de Madrid CSIC, Spain; Zoological Research Museum Alexander Koenig, Bonn, Germany; National Museum, Prague, Czech Republic. 